\title{
Flap Method is Better Than the Tubularized Incised Plate Method for the Surgical Treatment of Distal Hypospadias
}

\author{
Gede Wirya Kusuma Duarsa ${ }^{1 *}$, Samuel Denny Lawanto ${ }^{2}$, Anak Agung Gde Oka ${ }^{1}$, Kadek Budi Santosa ${ }^{1}$, I. Wayan Yudiana ${ }^{3}$, \\ Pande Made Wisnu Tirtayasa ${ }^{1}$, Ida Bagus Putra Pramana ${ }^{1}$, Christopher Ryalino ${ }^{4}$ \\ ${ }^{1}$ Department of Surgery, Division of Urology Surgery, Faculty of Medicine, Udayana University, Bali, Indonesia; ${ }^{2}$ Department \\ of Surgery, Faculty of Medicine, Udayana University, Bali, Indonesia; ${ }^{3}$ Division of Urology, Department of Surgery, Faculty of \\ Medicine Universitas Udayana, Bali, Indonesia; ${ }^{4}$ Department of Anesthesia and Intensive Care, Faculty of Medicine, Udayana \\ University, Bali, Indonesia
}

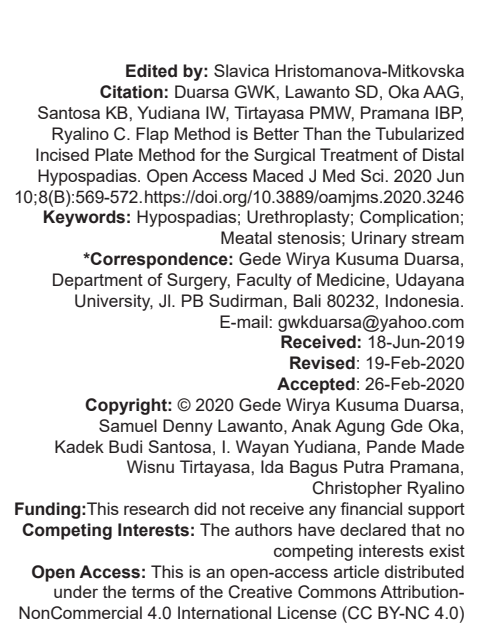

Abstract

BACKGROUND: Urethroplasty techniques generally can be divided into two methods, the flap method (Mathieu and Onlay Flap) and no flap with tubularized incised plate (TIP) urethroplasty method. Complications are common after urethral reconstructioninclude urethrocutaneous fistulae and cosmetic appearance, which is usually measured by Hypospadias Objective Penile Evaluation (HOPE) scoring system.

AIM: The aim of this study was to determine whether there are differences in the outcome of flap method compare to TIP method in distal hypospadias patients who underwent urethroplasty.

PATIENTS AND METHOD: The subjects of this study were patients with distal hypospadias who underwent urethroplasty in Sanglah General Hospital from September 2017 to December 2017. Thirty-six samples were selected by consecutive sampling

RESULTS: The results showed a significant difference in the incidence of meatal stenosis $(p=0.05)$ and urinary stream disturbances $(p=0.05)$ between two methods. No significant differences were found in the incidence of urethrocutaneous fistulae $(p=0.500)$ and the unsatisfactory HOPE score $(p=0.169)$.

CONCLUSION: This research showed that meatal stenosis andthe maximum urinary stream were better in flap method compared to TIP method in distal hypospadias patients underwent urethroplasty.

\section{Introduction}

Hypospadias is congenital abnormalities due to the failure of union of the urethral plate which results in abnormalities of the location of the external urethral meatus in male newborn. Its location varies along the ventral portion of the penis or in the perineum. The incidence of hypospadias is about 3.8 out of 1000 male live births [1], [2], [3], [4], [5]. Glanular hypospadias is the most common type of hypospadias reported. In our hospital, the most frequent type is penoscrotal (37.9\%) [6].

The purpose of urethroplasty or hypospadias correction is to achieve normal function and good appearance of the penis [5], [7]. The urethroplasty techniques are generally divided into two methods, the flap method (including Mathieu and flap onlay method) and method that does not use a flap such as tubularized plateu urethroplasty tubularized incised plate (TIP) method [4], [7], [8], [9], [10].

The most common complication occurs after Mathieu and TIP technique for urethroplasty are urethrocutaneous fistulae and meatal stenosis, which were reported at around 45\% [1], [5], [6], [11], [12], [13]. In addition, a complication can also occur including maximum urinary stream disruption and bad cosmetic appearance [8], [13], [14], [15], [16]. The cosmetic appearance of post-operative urethral reconstruction can be measured by a scoring system. The most used instrument for that objective was the Hypospadias Objective Penile Evaluation (HOPE) score [2], [6], [9].

The aim of this study was to compare the results of urethral reconstruction surgery using flap (Mathieu and Onlay) and without flap (TIP) method regarding functionality variables, including urethrocutaneous fistulae, meatal stenosis, maximum urinary stream, and the cosmetic aspect using HOPE scores.

\section{Materials and Methods}

This is a cross-sectional study conducted at Sanglah Hospital from September 2017 to December 
2017 using secondary data from medical records of the patients underwent urethroplasty for hypospadias repair. The inclusion criteria include all distal hypospadias patients underwent urethroplasty aged 1-20 years old at Sanglah General Hospital during the mentioned period. Those with incomplete medical records and refused to participate in this study were excluded from the study.

The subjects were categorized as those underwent flap method and those underwent TIP method. TIP method surgery procedure can be roughly explained as first a longitudinal incision is made in the midline of the urethral plate then urethral plate is polarized over the $8 \mathrm{Fr}$ catheter of the incised urethral plate, finally the glans of the penis glued in two layers, excessive skin is excised, and the catheter position is secured. A total of 18 subjects were enrolled to each group. Maximum urine emission (Qmax) is the maximum emission value based on age obtained based on the average urine emission value (Qavg) $x$ constant (2.07). It is called normal if Qmax is $10 \mathrm{ml} / \mathrm{s}$. A HOPE score was used as an instrument to assess the cosmetic aspect of the patient. It consists of the meatus position, meatus shape, glans shape, penile skin shape, and penile axis including penile torsion and (if observable erection) penile arch [2]. Penile cosmetic appearance is defined satisfying if the total score on HOPE questionnaire is greater than 45. HOPE score is evaluated by consultant urology specialist. The obtained data are presented in the narratives and tables and were analyzed using SPSS 21.0 software. A $p<0.05$ was considered statistically significant. The study protocol was approved by the Committee of Ethical Research of Udayana University/Sanglah General Hospital.

\section{Results}

One hundred and sixty-one hypospadias patients underwent urethral reconstruction from January 2010 to September 2017 at Sanglah Hospital. Of these 161 patients, 54 patients met the inclusion criteria and 36 samples were taken consecutively. Sample characteristics shown in Table 1.

Table 1: The subjects' characteristics

\begin{tabular}{lll}
\hline Characteristics & \multicolumn{3}{l}{ Urethroplasty method } \\
\cline { 2 - 3 } & $\operatorname{TIP}(\mathrm{n}=18)(\%)$ & Flap $(\mathrm{n}=18)(\%)$ \\
\hline Age (years) & $5.67 \pm 3.11$ & $4.44 \pm 1.46$ \\
$\quad$ Mean \pm SD & & \\
Complications & $2(11.1)$ & $1(5.6)$ \\
$\quad$ Urethrocutaneous fistulas, $\mathrm{n}(\%)$ & $8(44.4)$ & $0(0.0)$ \\
$\quad$ Meatal stenosis, $\mathrm{n}(\%)$ & $9(50.0)$ & $0(0.0)$ \\
Abnormal maximum urinary stream, $\mathrm{n}(\%)$ & $4(22.2)$ & $1(5.6)$ \\
Unsatisfactory HOPE score, $\mathrm{n}(\%)$ &
\end{tabular}

The comparison of complications between the TIP urethroplasty surgery method and the flap method shown in Table 2. The incidence of meatal stenosis and maximum urinary stream found to be statistically significance between two groups. However, the incidence of urethrocutaneous fistulae and the unsatisfied HOPE score was not statistically significance between those two groups.

Table 2: Complications observed based on the urethroplasty method

\begin{tabular}{|c|c|c|c|c|c|}
\hline \multirow[t]{2}{*}{ Variables } & \multicolumn{2}{|c|}{ Observed complications } & \multirow[t]{2}{*}{$\mathrm{RP}$} & \multirow[t]{2}{*}{$95 \% \mathrm{Cl}$} & \multirow[t]{2}{*}{$p$-value ${ }^{a}$} \\
\hline & Present (\%) & Absent (\%) & & & \\
\hline \multicolumn{3}{|c|}{ Urethrocutaneous fistulas } & 2.00 & $0.199-20.146$ & 0.5 \\
\hline TIP & $2(11.1)$ & $16(88.9)$ & & & \\
\hline Flap & $1(5.6)$ & $17(94.4)$ & & & \\
\hline \multicolumn{3}{|c|}{ Flap stenosis } & $N / A$ & $N / A$ & 0.001 \\
\hline TIP & $8(44.4)$ & $10(55.6)$ & & & \\
\hline Flap & $0(0.0)$ & $18(100.0)$ & & & \\
\hline \multicolumn{3}{|c|}{ Maximum urinary stream disruption } & N/A & N/A & 0.001 \\
\hline TIP & $9(50.0)$ & $9(50.0)$ & & & \\
\hline Flap & $0(100.0)$ & $0(100.0)$ & & & \\
\hline \multicolumn{3}{|c|}{ Satisfactory HOPE score } & 4.00 & $0.494-32.393$ & 0.169 \\
\hline TIP & $4(22.2)$ & $14(77.8)$ & & & \\
\hline Flap & $1(5.6)$ & $17(94.4)$ & & & \\
\hline
\end{tabular}

\section{Discussion}

In this study, we found that the relationship between urethrocutaneous fistulae based on the urethroplasty method was not in line with other studies. Braga et al. [13] and Bae et al. [8] reported that urethrocutaneous fistula in post-urethroplasty TIP surgery patients was significantly lower compared to post-urethroplasty flap patients. There are several factors that can affect the occurrence of urethrocutaneous fistula, including surgical techniques, patient age, presence or absence of surgical wound infections, and surgeon's preference and experience.

Snodgrass, who introduces the TIP technique, recommended the closure of neourethra using a twolayer tunica vaginalis flap to overcome urethrocutaneous fistulae. This is because by using one dartos flap, the urethrocutaneous fistulae can pass through the edge of the surgical wound. The urethrocutaneous fistula thus can go through a small perforation which can be caused by dissection during surgery, ischemic tissue, or infection. The insignificant difference regarding urethrocutaneous fistulae between two groups in this study can be due to high experience of a single surgeon performing this procedure [9], [13], [16], [17].

In this study, the incidence of meatal stenosis based on the urethroplasty method was similar with other studies. This could be related to the suture of the urethroplasty technique, which the flap method is more tension-free than the TIP method. Moreover, the meatal stenosis could be related to the TIP surgery technique that makes the external urethral meatus somewhat too distal. Furthermore, meatal stenosis can be caused by the formation of scar tissue along the surgical wound [1], [7], [8], [9], [13], [16], [18], [19]. 
The results of this study showed that the relationship between normal maximum urinary streams based on the urethroplasty method is similar with the research conducted by Bae et al. [8] which claimed that maximum urinary stream disruption in post-urethroplasty TIP patients is greater, compared with patients with posturethroplasty flap surgery. This is caused by several things such as pre-operative conditions. Wide urethral plate and deep urethral groove are found in TIP urethroplasty patients, so that the risk of scarring may directly lead to worse obstruction. In principle, the flap urethroplasty surgery is an urethroplasty technique that using a more minimal incision and with a shorter duration of surgery than TIP urethroplasty surgery. As a result, it can directly reduce the incidence of complications including the form of maximum urinary stream disruption [8], [19].

The relationship between the incidences of HOPE scores based on the urethroplasty method was not in line with other studies. Previous studies showed that the number of unsatisfied HOPE scores in post-urethroplasty TIP patients is higher significantly compared to that in the post-urethroplasty flap patients. This could be due to the fact that flap urethroplasty surgery is an urethroplasty technique using more minimal incision than TIP urethroplasty technique. In this study, the insignificant difference can be caused by high experience single surgeon [9], [13], [16], [17].

\section{Conclusion}

The incidence of meatal stenosis and the maximum urinary stream is significantly better in flap group than the TIP group. However, the incidence of urethrocutaneous fistulae, as well as unsatisfied HOPE scores, was not significantly different between the two groups.

\section{References}

1. Saleem MS, Rasool M, Pansota MS, Tabassum SA. Comparative study between tubularized incised plate (snodgrass) urethroplasty and reverse flap (mathieu's) repair in distal hypospadias. Ann Park Inst Med Sci. 2012;8(2):96-100. https://doi.org/10.18535/jmscr/v6i5.157

2. Toorn FV, de Jong TP, de Gier RP, Callewaert PR, van der Horst $\mathrm{EH}$, Steffens MG, et al. Introducing the HOPE (hypospadias objective penile evaluation)-score: A validation study of an objective scoring system for evaluating cosmetic appearance in hypospadias patients. J Pediatr Urol. 2013;9:1006-16. https://doi.org/10.1016/j.jpurol.2013.01.015 PMid:23491983

3. Aisuodionoe-Shadrach OI, Atim T, Eniola BS, Ohemu AA. Hypospadias repair and outcome in Abuja, Nigeria: A 5-year single-centre experience. Afr J Pediatr Surg. 2015;12:41-4. https://doi.org/10.4103/0189-6725.150977 PMid:25659549

4. Abdelrahman MY, Abdeljaleel IA, Mohamed E, Bagadi AT, Khair OE. Hypospadias in sudan, clinical and surgical review. Afr J Pediatr Surg. 2011;8(3):269-71. https://doi. org/10.4103/0189-6725.91654

\section{PMid:22248886}

5. Uygur MC, Erol D, Germiyanoglu C. Lessons from 197 mathieu hypospadias repairs performed at a single institution. Pediatr Surg Int. 1998;14(3):192-4. https://doi.org/10.1007/ s003830050484

PMid:9880746

6. Duarsa GW, Nugroho TD, Mahadewa TG, Yasa KP, Suryawisesa IB, Oka AA. Cosmetic Outcome of tubularized incised plate depends on the type of hypospadias: A case control study. Bali Med J. 2016;5(2):355-7. https://doi.org/10.15562/ bmj.v5i2.238

7. Dindar H, Yagmurlu A, Gokcora IH. Distal hypospadias repair: Comparison of two different techniques. Int Urol Nephrol. 2014;33(1):113-6.

PMid:12090315

8. Bae SH, Lee JN, Kim HT, Chung SK. Urethroplasty by use of turnover flaps (modified mathieu procedure) for distal hypospadias repair in adolescents: Comparison with the tubularized incised plate procedure. Korean J Urol. 2014;55(11):750-5. https://doi.org/10.4111/kju.2014.55.11.750 PMid:25405018

9. Xiao D, NieX, Wang W, Zhou J, Zhang M, Zhou Z, etal. Comparison of the transverse island flap onlay and tubularized incised-plate urethroplasties for primary proximal hypospadias: A systematic review and meta-analysis. PLos One. 2014;9(9):e106917. https://doi.org/10.1371/journal.pone.0106917 PMid:25197970

10. Hayashi $\mathrm{Y}$, Sasaki S, Kojima Y, Maruyama T, Tozawa K, Mizuno $\mathrm{K}$, et al. Primary and salvage urethroplasty using mathieu meatal-based flip-flap technique for distal hypospadias. Int J Urol. 2001;8(1):10-6. https://doi. org/10.1046/j.1442-2042.2001.00237.x PMid:11168691

11. Shehata S, Hashish M. Current Concept of Urethroplasty. Rijeka: InTech; 2011.

12. Srivastava RK, Tandale MS, Panse N, Gupta A, Sahane P Management of urethrocutaneus fistula after hypospadias surgery-an experience of thirty five cases. Indian J Plast Surg. 2011;44(1):98-103. https://doi.org/10.4103/0970-0358.81456 PMid:21713169

13. Braga LH, Lorenzo AJ, Salle JL. Tubularized incised plate urethroplasty for distal hypospadias: A literature review. Indian J Urol. 2008;24(2):219-25. https://doi. org/10.4103/0970-1591.40619 PMid: 19468401

14. Wolffenbuttel KP, Wondergem N, Hoefnagels JJ, Dieleman GC Pel JJ, Passchier BT, et al. Abnormal urine flow in boys with distal hypospadias before and aftercorrection. JUrol. 2006;176(4):17336. https://doi.org/10.1016/s0022-5347(06)00614-8 PMid: 16945635

15. Kajbafzadeh A, Yazdi CA, Rouhi $O$, Tajik $P$, Mohseni $P$ Uroflowmetry nomogram in iranian children aged 7 to 14 years. BMC Urol. 2005;5:3. https://doi.org/10.1186/1471-2490-5-3

16. Gurdal M, Tekin A, Kirecci, S. Intermediate-term functional and cosmetic results of the snodgrass procedure in distal and midpenile hypospadias. Pediatr Surg Int. 2004;20(3):197-9. https://doi.org/10.1007/s00383-004-1146-2 


\section{PMid:15064965}

17. Springer A, Krois W, Horcher E. Trends in hypospadias surgery: Results of a worldwide survey. Eur Urol. 2011;60(6):1184-9. https://doi.org/10.1016/j.eururo.2011.08.031

PMid:21871708

18. Nezami BG, Mahboubi AH, Tanhaeivash R, Tourchi A, Kajbafzadeh AM. Hypospadias repair and glans augmentation using a modified mathieu technique. Pediatr Surg Int. 2010;26(3):299-303. https://doi.org/10.1007/s00383-009-2526-4 PMid: 19915855

19. Scarpa MG, Castagnetti M, Berrettini A, Rigamonti W, Musi L. Urinary function after snodgrass repair of distal hypospadias: Comparison with the mathieu repair. Pediatr Surg Int. 2010;26(5):519-22. https://doi.org/10.1007/s00383-010-2569-6 